\title{
Simultaneous enumeration of Phaeodactylum tricornutum (MLB292) and bacteria growing in mixed communities
}

\author{
Katia Soto ${ }^{1}$, Gloria Collantes ${ }^{2}$, Marcela Zahr ${ }^{3}$ \& Juan Kuznar ${ }^{1}$ \\ ${ }^{1}$ Laboratorio de Bioquímica y Virología, Facultad de Ciencias \\ Universidad de Valparaíso, Valparaíso, Chile \\ ${ }^{2}$ Laboratorio de Ficología, Facultad de Ciencias del Mar \\ Universidad de Valparaíso, Valparaíso, Chile \\ ${ }^{3}$ Laboratorio de Microbiología, Facultad de Ciencias \\ Universidad de Valparaíso, Valparaíso, Chile
}

\begin{abstract}
Diatoms play a decisive role in global primary production, have a key role in the marine food web, and serve as food for the industrial culture of aquatic animals. In addition, species of diatoms have been chosen as tools for measuring sea water quality and for bioassay procedures. Among them, Phaeodactylum tricornutum (Bohlin) Lewin, 1958, represents a good biological model due to its ease of handling and also to its physiological, genetic and growth characteristics. We investigated the use of the Epifluorescence Microscopy (EPM) to visualize and enumerate $P$. tricornutum cells and bacteria in cultures containing both kinds of microorganisms. The cell suspension was filtered, stained with SYBR Green and analyzed by EPM. P. tricornutum can be enumerated using EPM with comparable accuracy as using a hemocytometer. The same kind of growth curve is obtained with either method. EPM is an advantageous alternative to the classic light microscope counting method; it allows the simultaneous enumeration of $P$. tricornutum and bacteria in a single sample, measuring red autofluorescence and green fluorescence respectively. Moreover, the methodology is suitable for dynamic studies performed to determine the growth dependence between $P$. tricornutum and bacteria. Another advantage of this technique is that different shapes, sizes and physiological stages of the microbiological communities can be observed.
\end{abstract}

Key words: microscopic algae, bacteria, growth, enumeration, epifluorescence.

\section{Enumeración simultánea del crecimiento de Phaeodactylum tricornutum (MLB292) y bacterias en comunidades mixtas}

RESUMEN. Las diatomeas tienen un rol decisivo en la producción primaria global, un rol clave en la red trófica marina y sirven como alimento en el cultivo industrial de animales acuáticos. Algunas especies han sido elegidas para medir la calidad del agua y para bioensayos. Entre ellas, Phaeodactylum tricornutum (Bohlin) Lewin, 1958, representa un buen modelo biológico debido a su fácil manejo, como también a sus características fisiológicas, genéticas y de crecimiento. Se analiza el uso de la Microscopía de Epifluorescencia (MEP) para visualizar y enumerar células de $P$. tricornutum y bacterias en cultivos que contienen ambos tipos de microorganismos. Las células en suspensión fueron filtradas, marcadas con SYBR Green y analizadas con MEP. Las células de P. tricornutum se pueden contar con una precisión comparable a la del hemocitómetro y se obtiene la misma curva de crecimiento con ambos métodos. La MEP es una alternativa ventajosa al uso del clásico microscopio de luz, ya que permite el recuento simultáneo de $P$. tricornutum y bacterias en una misma muestra, midiéndose la autofluorescencia roja y la fluorescencia verde, respectivamente. Más aún, la metodología es apropiada para estudios de dinámica y para determinar la dependencia entre el crecimiento de P. tricornutum y las bacterias. Otra ventaja de esta técnica es que se puede observar diferencias de forma, tamaño y estado fisiológicos de las comunidades microbiológicas.

Palabras clave: algas microscópicas, bacterias, crecimiento, enumeración, epifluorescencia. 


\section{INTRODUCTION}

Microscopic algae are a large and diverse group of photosynthetic organisms. They play an important role in the production of oxygen and organic materials; they present a diversity of connections with members of the microbial community of the marine food web, serving as a food source for different species in open environments as well as for aquatic animals in industrial culture. In addition, microscopic algae have become great biotic indicators of environmental changes and/or human induced alterations. In order to monitor them, reliable methods are progressively required for measuring their growth in nature and in laboratory conditions.

Epifluorescence microscopy of chlorophylls is utilized as a tool in phytoplankton studies. Forward angle light scatter (related to cell size), $90^{\circ}$ side scatter (related to cell shape) and three fluorescence emission bands (related to pigments) are usually measured. This allows sub-populations of algal cultures and natural phytoplankton populations to be distinguished and quantified (Booth, 1995). Fluorescent stains specific for nucleic acids or proteins can also be used (Yentsch et al., 1983), allowing thus, the measurement of large numbers of particles (Jeffrey, 1997).

Diatoms, among microscopic algae, are components of marine phytoplankton being very important for biogeochemical cycling of minerals and carbon fixation. Due to their great ecological and practical importance it is mandatory to select reliable models among diatom species. Phaeodactylum tricornutum represents a good biological model due to its ease of culture handling, short generation times and also its physiological and genetics characteristics (Bonin et al., 1986; Dunahay et al., 1995, 1996; Apt et al., 1996; Bowler et al., 2002).

It is important to consider other microbial populations which grow together with microscopic algae. There is evidence supporting the cross influences between algae and bacteria in mixed communities. Bacteria can exert positive or negative effects on growth of microscopic algae. Moreover, the control of bacterial growth by microalgae and microalgal extracts for aquacultural purposes was determined recently in Isochrysis, Tetraselmis and Nannochloropsis cultures (Rodolfi et al., 2004).
In this research we further explore the use of epifluorescence microscopy as a tool to follow the progress of cultures of the diatom P. tricornutum and, in addition, it is shown that this methodology can be useful to enumerate and visualize bacterial communities whose growth rates are coupled to that of $P$. tricornutum.

\section{MATERIALS AND METHODS}

\section{Growth measurement of $P$. tricornutum}

Aliquots of $200 \mu \mathrm{L}$ of a $4 \times 10^{6}$ cell $\cdot \mathrm{mL}^{-1} P$. tricornutum (MLB292) culture were inoculated into $9 \mathrm{~mL}$ of Provasoli culture medium (PES) (Provasoli, $1968)$ in 42 replicas. Each culture was maintained at $16^{\circ} \mathrm{C}$ and $50 \mu \mathrm{mol}$ photons $\cdot\left(\mathrm{m}^{2} \cdot \mathrm{s}\right)^{-1}$ of continuous illumination. The enumeration of the cells was performed with two light microscopy - based methodologies; counting cells in an hemocytometer (0.1 mm deep) with standard light microscopy (Guillard, 1973) and counting green fluorescent cells stained with SYBR Green I, (Molecular Probes Inc.) (Paul, 2001), and the autofluorescence of their photosynthetic pigments (Booth, 1995). To collect the microbes to be analyzed by epifluorescence microscopy $9,5,2,0.5$ and $0.2 \mathrm{~mL}$ of the cultures were filtered through a $0.02 \mu \mathrm{m}$ pore membrane (Anodisc, Whatman). The volumes were chosen according to the daily increase of the concentration of $P$. tricornutum during the experiments determined by hemacytometer counts (Guillard, 1973).

\section{Bacterial isolation, viable plate counts and biomass determination}

The cell suspension was plated directly on Marine Agar (DIFCO) to obtain isolated bacterial colonies. Each different colony observed, was streaked on Marine Agar plates to re-isolate and purify the bacteria and then perform a Gram stain. For viable bacterial counting, 10 fold dilutions were made from the cell suspension and from each dilution; $0.1 \mathrm{~mL}$ was spread over the surface of the Marine Agar plates. The colonies were counted after 2, 4, 6 and 8 days of incubation at $15^{\circ} \mathrm{C}$. The biomass of the bacterial population was calculated from the microscope images applying the allometric formulae described for fluorescent stained bacteria (Posch $e t$ al., 2001). Width and length of each cell was provided by the software. 


\section{Staining of algae and bacteria}

The SYBR Green I method as Noble (2001) described was used. The algae were previously fixed with formaldehyde $(1.5 \%)$ during $30 \mathrm{~min}$ and filtered through Anodic discs. The filter with the retained material was placed over a drop of SYBR Green I standard solution (Molecular Probes Inc.) diluted 1:1000 in Milli Q water. After 15 min in the dark at room temperature, the excess of stain was removed vacuum washing the filter three times with Milli Q water. The filter was removed from the vacuum equipment, before turning it off and placed on a glass slide and covered with a $25 \mathrm{~mm}$ square glass containing a drop of anti-fade mounting solution (50\% PBS/50\% glycerol with $0.1 \%$ p-phenylenediamine).

The stained samples were examined in an Olympus BX60 epifluorescence microscope. Randomly selected fields were counted in order to enumerate about 200 microscopic algae or 250 bacteria per filter. The fluorescent samples were examined with WIB and WIG filters. Excitation 460$490 \mathrm{~nm}$, emission $515 \mathrm{~nm}$ and excitation 520-550 $\mathrm{nm}$, emission $580 \mathrm{~nm}$ were used respectively.

The counting of particles was done using the Image Pro® Plus 4.5 (Media Cybemetics) software. It is worth to recall that this software allows a direct counting of the stained elements without previous processing of images. To achieve a proper differentiation between bacteria and micro algae, the threshold was adjusted with the upper limit of pixels for bacteria well below the lower limit of pixels for micro algae.

\section{RESULTS}

P. tricornutum can be enumerated using epifluorescence microscopy, coupled with appropriate software, with comparable accuracy to that of the hemocytometer counting device (Fig. 1).

Different kinds of microorganisms can be enumerated from the same sample allowing quantitative and dynamic analysis of mixed communities. $P$. tricornutum and bacteria reached their stationary state at the same time, after 4 days (Fig. 2). In addition to the monitoring of cell number during cell multiplication, when bacterial biomass is calculated for each sampled time, it can be seen that after day four, even if the cell number increases slightly - or remains constant - the bacterial biomass

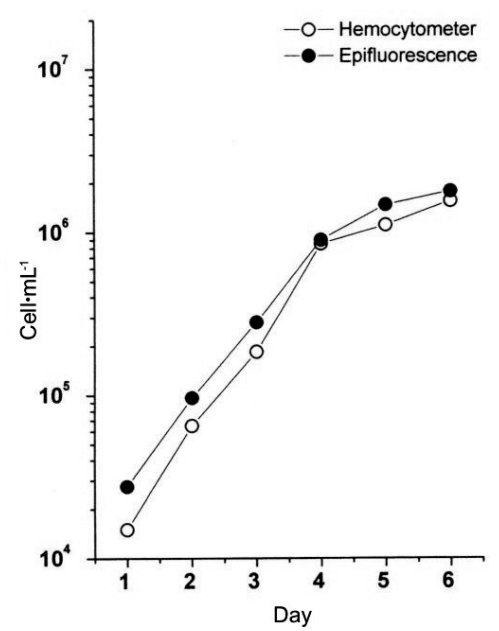

Figure 1. Enumeration of $P$. tricornutum using epifluorescence or standard light microscopy. The difference between replicas never exceeded $5 \%$ in both methods as them were used.

Figura 1. Enumeración de $P$. tricornutum mediante epifluorescencia o microscopía óptica estándar. Las diferencias entre las réplicas nunca superaron el 5\% en las condiciones en que ambos métodos se usaron.

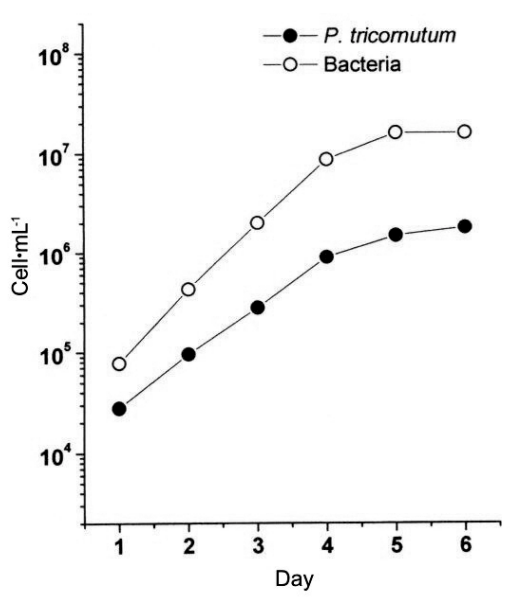

Figure 2. Simultaneous enumeration of $P$. tricornutum and bacteria using epifluorescence.

Figura 2. Enumeración simultánea de $P$. tricornutum y bacterias mediante epifluorescencia. 
decreases more than four fold (Fig. 3). The inlets of this figure show that size differences of stained bacteria are easily visualized.

Different morphotypes and reproductive forms are concurrently seen in cultures of $P$. tricornutum: fusiform, triradiate, cruciform and oval. Taking advantage of the red autofluorescence of $P$. tricornutum pigments, these can be easily distinguished during the development of the culture. The fusiform shape (over 90\%) predominates during all the growth cycle (Fig. 4a). When it is present (less than 2\%), the P. tricornutum triradiate form is easily visualized (Fig. 4b). At the stationary phase or close to it, spherical forms, or auxospores, were also seen (Fig. 4c) and morphological variants of the chloroplast during cell division can be appreciated as well (Fig. 4d).

The P. tricornutum MLB292 used in our experiments was not maintained in axenic conditions; in addition, they were passaged several times before being used. In these conditions we would expect that a few different kinds of bacteria were selected. When samples were taken from the cell suspension containing $P$. tricornutum, and plated on Marine Agar, few types of bacterial colonies were seen; as an example, at day 2 only two types of colonies were seen (Fig. 5a). We are aware that few marine bacteria can be grown in these conditions, however, as shown in Figures $4 \mathrm{a}$ and $5 \mathrm{c}$ a rather uniform pattern of bacillar forms are also seen in the liquid culture medium. When the bacteria growing together with $P$. tricornutum were quantified by the colony counting method, we found, indeed, that the majority of the enumerated colonies corresponded to the bacteria shown in Figure 5b. Furthermore, the concentration of bacteria measured by the colony counting method was quite similar to the concentration determined by the epifluorescence method.

\section{DISCUSSION}

The standard procedures for enumerating natural populations of microscopic algae require the use of the inverted microscope or separable setting chambers with the ordinary microscope. The latter may be used if a culture is too dilute to count optically without concentration of the sample. Therefore, counting methods suited for algal cultures use several different devices depending on cell sizes and culture densities. In the case of cell enumeration

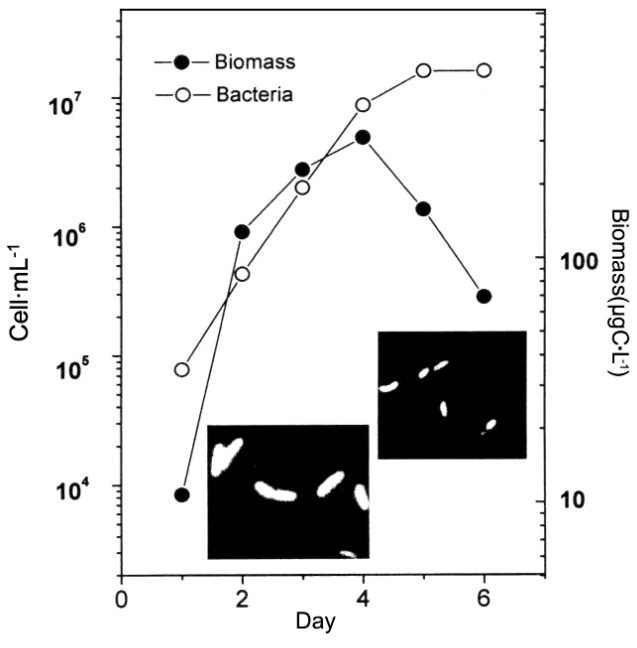

Figure 3. Biomass of bacteria along growth curve. The biomass of the bacterial population was calculated from the microscope images applying the allometric formulae described for fluorescent stained bacteria (Posch et al., 2001). The photographs in the inlets were taken at the corresponding times.

Figura 3. Biomasa bacteriana durante el ciclo de crecimiento. La biomasa bacteriana fue calculada desde las imágenes del microscopio usando la fórmula alométrica descrita para bacterias teñidas fluorescentemente (Posch et al., 2001). Las fotografías de los recuadros internos fueron tomadas a los tiempos correspondientes.

by epifluorescence, the samples can be immediately analyzed because the method implies the direct counting of the cells concentrated on the filter.

The eye counting procedure can be more or less time consuming depending on the training of the technician and could be tedious if many samples need to be analyzed as well. Counting fluorescent cells using a software minimizes these inconvenient. Moreover, digitalized images can be saved as permanent records that can be processed further. Stained samples can also be preserved provided that they are kept with a mounting solution and at $-20^{\circ} \mathrm{C}$. In case that only microscopic algae are to be enumerated, no staining is required. Autofluorescence of cell pigments can be used for that purpose diminishing the time required for the whole cell counting process.

The fact that bacteria and $P$. tricornutum reached their stationary state together after four days, suggests a mutual dependence. Moreover, when we added an antibiotic to the culture medium, the 

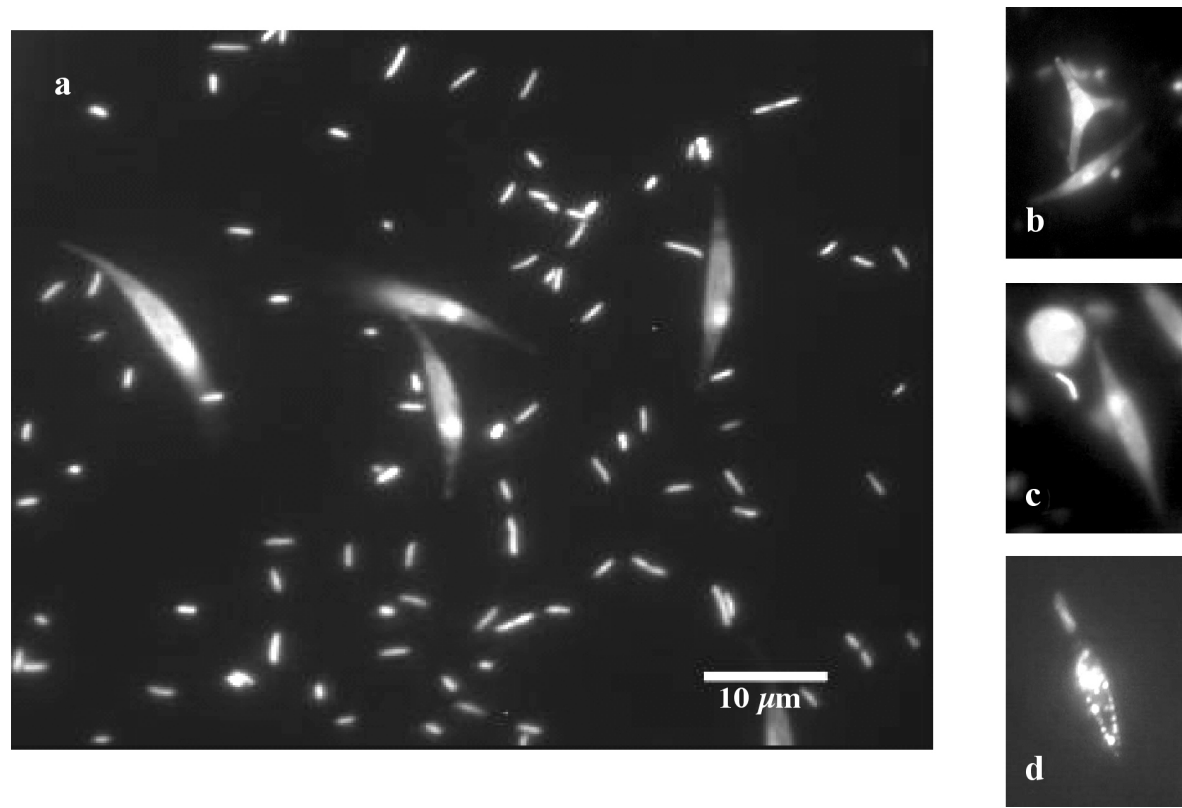

Figure 4. Epifluorescence microscopy of a cell suspension containing $P$. tricornutum and bacteria. a) $P$. tricornutum and bacterial cells. b) triradiate and fusiform shapes of $P$. tricornutum. c) auxospore of $P$. tricornutum. d) chloroplast in $P$. tricornutum during cell división. Green; fluorescence from SYBR Green I staining (nuclei of $P$. tricornutum and bacteria). Red; autofluorescence from photosynthetic pigments (cytoplasm of $P$. tricornutum).

Figura 4. Microscopía de fluorescencia de una suspensión que contiene $P$. tricornutum y bacterias. a) $P$. tricornutum y bacterias. b) formas trirradiadas y fusiformes de $P$. tricornutum. c) auxospora de $P$. tricornutum. d) cloroplasto en $P$. tricornutum durante la división celular. Fluorescencia de la tinción con SYBR Green I (núcleos de $P$. tricornutum y bacteria, verde). Autofluorescencia de los pigmentos fotosintéticos (citoplasma de $P$. tricornutum, rojo).
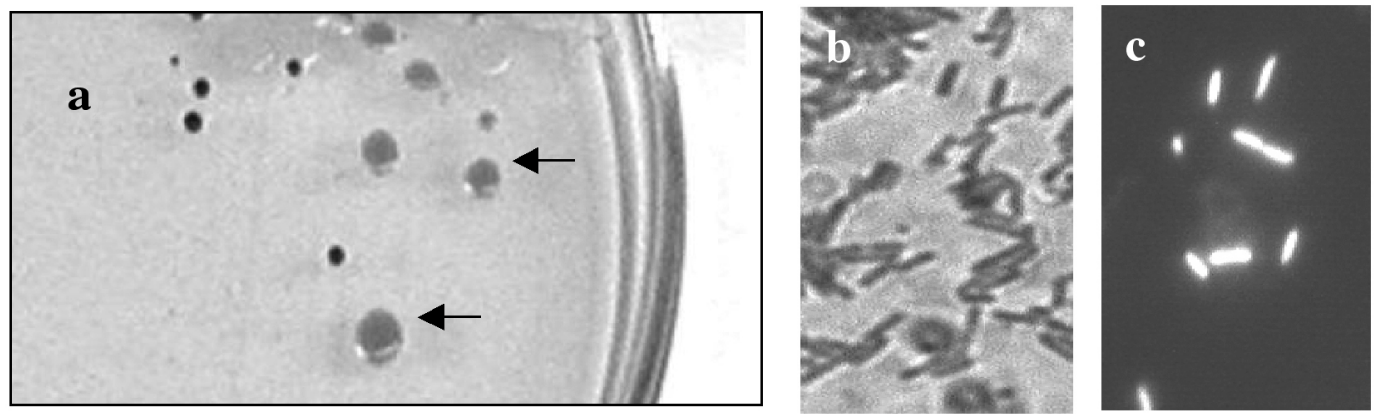

Figure 5. Bacteria isolated from $P$. tricornutum cultures. a) Colonies isolated from $P$. tricornutum culture at day 2 (samples from experiment shown in figure 2), two different types of colonies are visualized. b) Gram negative stained bacteria grown from the most abundant colony type in the plate (arrows). c) SYBR Green I stained bacteria observed in $P$. tricornutum cultures at day 2.

Figura 5. Bacterias aisladas desde cultivos de $P$. tricornutum. a) Colonias aisladas desde cultivos de $P$. tricornutum en el día 2 (muestras de experimentos mostrados en la figura 2), se visualizan dos tipos diferentes de colonias. b) Bacterias Gram negativas provenientes del tipo de colonia más abundante presente en la placa (flechas). c) Bacterias teñidas con SYBR Green I observadas en cultivos de $P$. tricornutum al día 2. 
growth of $P$. tricornutum was reduced to less than $10 \%$ (not shown). This relation between a microscopic algae and bacteria is worth being handled experimentally and monitored because the optimal growth conditions of a microscopic alga usually requires specific accompanying bacteria (Suminto \& Hirayama, 1996; Fukami et al., 1997). This close bacterial-algal association is very important. $P$. tricornutum like other phytoplankton algae would excrete a variety of organic compounds, including amino acids, peptides, carbohydrates, and lipopolysacharides. These can serve as sources of fixed carbon and nitrogen for adherent bacteria. Bacteria may, in turn, provide growth factors, vitamins, chelors, or remineralized inorganic nutrients (Graham \& Wilcox, 2000).

Another advantage of the epifluorescence methodology is that different shapes, sizes and physiological stages of the microbial communities can be appreciated (Fig. 4). The interdependent growth of bacteria and P. tricornutum can be further analyzed from the curves providing that differences can be detected among bacteria during cocultivation. As shown in Fig. 4, qualitative differences make it possible to measure changes in bacterial biomass. With our data it is not possible to asses if the size of bacteria, late in $P$. tricornutum growth curve, corresponds to a decrease in cellular volume of the bacteria or to a replacement of big sized bacteria by a different population of smaller bacteria.

The reduction of $P$. tricornutum growth could be related to the decline of bacterial biomass. It is tempting to deduce that the reduced bacterial biomass is an effect of a decreased metabolic activity, which in turn, implies less exportation of a nutrient required by $P$. tricornutum. Microscopic algae, as $P$. tricornutum, are commercially grown in order to provide food for molluscs and shrimp in massive cultures. It is well known that bacteria can stimulate or inhibit the growth of microscopic algae in nature and controlled cultures (Fukami et al., 1997). Consequently, it is of great interest to have tools to allow the monitoring and selection of bacteria which confer the proper stimulation conditions for a given microscopic algae.

As a whole, our results show that epifluorescence microscopy is a reliable tool to follow the kinetics of $P$. tricornutum growth and the accompanying bacteria. The sizes and shapes of the stained microorganisms can be used to estimate their biomasses together with their reproductive and physiological status. P. tricornutum provides live food for commercially important molluses, crustaceans and fish during part of their life cycles. Therefore, epifluorescence microscopy could be a reliable tool to follow the growth kinetics of a variety of microscopic algae allowing the monitoring and selection of bacteria which provide stimulation conditions for a given microscopic algae.

There are a number of projects underway around the world attempting to develop strategies for the mass culture of microscopic algae and for the production of fine chemicals; of those which are in an advanced stage of development, $P$. tricornutum has been chosen as useful for aquaculture purposes. $P$. tricornutum has also been successfully transformed using genetic engineering in order to improve lipid production (Dunahay et al., 1996; Apt et al., 1996). P. tricornutum grown outdoors in a tubular photobioreactor produces high biomasses suitable for extraction of eicosapentaenoic acid, a long-chain polyunsaturated fatty acid used as a human food supplement (Alonso et al., 1996), dietary supplement in aquaculture and as substrate for synthesis in the pharmaceutical industry (Borowitzca, 1988). One of the most widely used algal biomonitors for seawater is $P$. tricornutum. This alga is recommended for use in tests such as the (U.S.) Environmental Protection Agency's Algal Assay Procedures, the similar Algal Growth Potential Test, and the Algal Growth Inhibition Toxicity Test (Graham \& Wilcox, 2000).

Growth of microscopic algae is sensitive to the stimulatory or inhibitory action of bacteria. Therefore it is important to monitor the bacterial communities that influence the growth pattern of microscopic algae. Aquaculturists and other professionals interested in the improvement of mass cultures of microscopic algae can improve their yields by promoting the growth of particular bacteria together with the algae. In order to select the bacteria, it is practical to find which of them have a growth kinetic behavior, suggesting an interdependent relation between them and microscopic algae. We believe that the results presented in this manuscript contribute to improve the tools available for monitoring the growth conditions of mixtures of $P$. tricornutum and bacteria allowing thus an easier handling of the cultures and the selection of the appropriate bacteria and microscopic algae for future growth of these mixed cultures. Ultimately cultivation of $P$. tricornutum as source of eicosapentanoic acid is of interest to improve herbivores food. 


\section{REFERENCES}

Alonso, DX., C.I.S. del Castillo, E.M. Grima \& Z. Cohen. 1996. First insights into improvement of eicosapentanoic acid content in Phaeodactylum tricornutum (Bacillariophyceae) by induced mutagenesis. J. Phycol., 32: 339-345.

Apt, K.E., P.G. Korth-Pancic \& A.R. Grossman. 1996. Stable transformation of the diatom Phaeodactylum tricornutum. Mol. Gen. Genet., 252: 572-579.

Bonin, D.J., M.R. Droop, S.Y. Maestrini \& M.C. Bonin. 1986. Physiological features of six microalgae to be used as indicators of seawater quality. Cryptog. Algol., 7(1): 23-83.

Booth, B.C. 1995. Estimación de la biomasa del plancton autotrófico usando microscopía. In: K. Alveal, M.E. Ferrairo, E.C. Oliveira \& E. Sar (eds.). Manual de métodos ficológicos, Universidad de Concepción, Concepción, pp.187-198.

Bowler, Ch., M.L. Chiusano, A. Falciatore, A. Carels \& S. Scala. 2002. Genome properties of the diatom Phaeodactylum tricornutum. Plant Physiol., 129: 993-1002.

Borowitzka, M.A. 1988. Vitamins and fine chemicals from micro-algae. In: M.A. Borowiska \& L.J. Borowiska (eds.). Micro-algae for aquaculture. Micro-algal biotechnology. Cambridge University Press, New York, 7: 153-196.

Dunahay, T.G., E.E. Jarvis \& P.E. Roessler. 1995. Genetic transformation of the diatom Cyclotella cryptica and Navicula saprophila. J. Phycol., 31: 1004-1012.

Dunahay, T.G., E.E. Jarvis, S.S. Dais \& P.G. Roessler. 1996. Manipulation of microalgal lipid production using genetic engineering. Appl. Biochem. Biotech., 58: 223-231.

Fukami, K., T. Nishijima \& Y. Ishida. 1997. Stimulative and inhibitory effects of bacteria on the growth of microscopic algae. Hydrobiol., 358: 185-191.

Graham, L.E. \& L.W. Wilcox. 2000. Algae. Prentice Hall, New Jersey, 640 pp.
Guillard, R. 1973. Division rates. In: J. Stein (ed.). Handbook of phycological methods. Cambridge University Press, New York, pp. 289-311.

Jeffrey, W. 1997. Application of pigment methods to oceanography. In: S.W. Jeffrey, R.F.C. Mantoura $\&$ S.W. Wright (eds.). UNESCO Publishing, Paris, pp. 127-161.

Noble, R. 2001. Enumeration of viruses. In: J. Paul (ed.). Methods in microbiology, marine microbiology. Academic Press, London, 30: 437-448.

Paul, J. (ed.). 2001. Methods in microbiology, marine microbiology. Academic Press, London, 666 pp.

Posch, T., M. Loferer-Krobacher, G. Gao, A. Alfreider, J. Pernthaler \& R. Psenner. 2001. Precision of bacterioplankton biomass determination: a comparison of two fluorescent dyes, and allometric and linear volume-to-carbon conversion factors. Aquat. Microb. Ecol., 25: 55-63.

Provasoli, L. 1968. Media and prospects for the cultivation of marine algae. In: A. Watanabe \& A. Hattori (eds.). Proceedings of the U.S. Japan Conference Hakone, Sept. 1966. Cultures and collection of algae. Japanese Society of Plant Physiology, pp. 63-75.

Rodolfi, L., N. BiondiBacchetti, T. De Gregoris, G. Chini Zittelli, S. Somigli \& M.R. Tredici. 2004. Control of bacterial growth by microalgae and microalgal extracts for aquacultural purposes. Libro de Resúmenes, $1^{\text {er }}$ Congreso latinoamericano sobre biotecnología algal, 25-29 octubre 2004, Buenos Aires, Argentina, 168 pp.

Suminto, I. \& K. Hirayama. 1996. Effects of bacterial coexistence on the growth of a marine diatom Chaetoceros gracilis. Fish. Sci., 62(1): 40-43.

Yentsch, C.M., P.K. Horan, K. Muirhead, Q. Dorch, E. Haugen, L. Legendre, L.S. Murphy, M.J. Perry, D.A. Phinney, S.A. Pomponi, R.W. Spinrad, M. Wood, C.S. Yentsch \& B.J. Zahuranec. 1983. Flow cytometry and cell sorting: a technique for analysis and sorting of aquatic particles. Limnol. Oceanogr., 28: 1275-1280. 